\title{
Profile of nursing mothers and infants attended at the primary health care unit
}

\author{
Perfil de nutrizes e lactentes atendidos na Unidade de Atenção Primária de Saúde \\ Perfil de lactantes y lactantes atendidos en la Unidad de Atención Primaria de Salud
}

Rebecca Camurça Torquato ${ }^{1}$ Vanusa Maria Gomes Napoleão Silva ${ }^{1}$

Ana Paola de Araújo Lopes ${ }^{1}$ Lidiane do Nascimento Rodrigues ${ }^{1}$ Wandra Camila Penaforte da Silva ${ }^{1}$ Edna Maria Camelo Chaves $^{1}$

1. Universidade Estadual do Ceará.

Fortaleza, Ceará, Brazil.
Corresponding author:

Lidiane do Nascimento Rodrigues.

E-mail: lidianerodrigues09@gmail.com

Submitted on $07 / 27 / 2017$

Accepted on 11/24/2017.

DOI: 10.1590/2177-9465-EAN-2017-0212

\section{Abstract}

Objective: To characterize the profile of nursing mothers and infants consulted in primary health care. Methods: This descriptive, cross-sectional quantitative study of 135 nursing mothers used a questionnaire with open and closed questions for data collection. Results: The ages of most mothers were in the range of 20 to 35 years. The majority lived with their partner, had completed high school and did not have formal employment. Most were primipara and had participated in between three to seven prenatal consultations in primary care. Most had full term pregnancies with delivery by C-section. The difficulties presented in breastfeeding leading to the nursing mothers to use infant formulas early were fissures, pain, breast engorgement and mastitis. Conclusion: The study participants were young mothers of childbearing age with a good level of schooling. However, low rates of breastfeeding were evidenced.

Keywords: Newborn; Breastfeeding; Primary Health Care.

\section{Resumo}

Objetivo: Caracterizar o perfil de nutrizes e dos lactentes atendidas na atenção primária de saúde. Métodos: Estudo descritivo e transversal com abordagem quantitativa, desenvolvido com 135 nutrizes utilizando-se um formulário com perguntas abertas e fechadas para obtenção dos dados. Resultados: O predomínio da faixa etária das nutrizes variou de 20 a 35 anos. A maioria residia com o companheiro, tinham o ensino médio completo e não possuíam emprego formal. A maioria era primípara, havia realizado entre três a sete consultas de pré-natal na atenção primária. Foi prevalente a gestação a termo e o parto cesáreo. As dificuldades apresentadas na amamentação foram: fissuras, dor ao amamentar, ingurgitamento mamário e mastite, levando-as ao uso de fórmulas infantis precocemente. Conclusão: As participantes do estudo foram nutrizes jovens, em idade fértil e com bom nível de escolaridade. No entanto, foi evidenciado baixos índices de aleitamento materno.

Palavras-chave: Recém-nascido; Aleitamento Materno; Atenção Primária à Saúde.

\section{Resumen}

Objetivo: Caracterizar el perfil de las mujeres y los lactantes atendidos en la atención primaria de salud. Métodos: Estudio descriptivo y transversal, de tipo cuantitativo, desarrollado con 135 nutriciones usando un formulario de preguntas abiertas y cerradas. Resultados: El grupo predominante de edad de las nutriciones varía entre los 20 a 35 años. La mayoría residía con el compañero, tenían la enseñanza media completa y no poseian empleo formal, era primípara y habían realizado entre tres a siete consultas de prenatal en la atención primaria. Fue prevalente la gestación a término y el parto cesáreo. Las dificultades en la lactancia fueron: fisuras, dolor al amamantar, ingurgitación mamaria y mastitis, llevándolas al uso de fórmulas infantiles precozmente. Conclusión: Las participantes del estudio eran jóvenes, en edad fértil y con buen nivel de escolaridad, pero, se evidenció un bajo índice de lactancia materna.

Palabras clave: Recién nacido; Lactancia Materna; Atención Primaria a la Salud. 


\section{INTRODUCTION}

Breastfeeding is a biological, cultural and social process. Among the premises that favor breastfeeding are the reduction in episodes of diarrhea, respiratory infections, allergies, hypertension and risks of cholesterol and diabetes in adult life; reduction of infant mortality and obesity rates; protection against breast cancer and prevention of another pregnancy during the puerperal period, besides promoting an affective bond between mother and child. ${ }^{1}$

However, despite all the scientific evidence proving the superiority of breastfeeding over other ways of feeding the child for its first six months and despite the efforts of several national and international organizations, breastfeeding rates in Brazil, especially rates of breastfeeding without using infant formulas, recommended until the sixth month of the baby's life, are well below the recommended level. ${ }^{1}$

Results of a systematic review show that women often do not know the context of breastfeeding or are not yet prepared for it, leaving them vulnerable to difficulties during the process. ${ }^{2}$ Among these, the most frequent are: pain and discomfort in the nipple when breastfeeding, inadequate positioning of the newborn, breast engorgement and fissures, which are considered important enough causes to abandon this type of feeding. ${ }^{3}$

Strategies to promote breastfeeding should be developed both in hospitals and in primary health care units. ${ }^{4}$ The Family Health Strategy is also considered a propitious environment for activities aimed at encouraging breastfeeding, since it is a space where community health issues can be resolved and where community members are received, listened to and offered solutions to health problems, thereby providing integral care to all individuals.

The health professional is fundamental in the prevention of difficulties related to breastfeeding and for interventions, both of which require specific knowledge, attitudes and skills. ${ }^{5}$ In this context, the nurse, as the professional who maintains the most contact with patients, needs to be prepared to guide nursing mothers, who, as they do not always have the maternal ability to take care of and breastfeed the newborn, have difficulties and consider the act of breastfeeding unpleasant. ${ }^{6}$

In view of the foregoing, knowing the profile of nursing mothers is essential to provide support to health services in the planning of quality care. In that way, the nursing mother can establish an affective bond with her baby and be successful during this phase. There are many studies on breastfeeding in the literature, especially with regard to difficulties and early weaning, but there is still little research on the profile of nursing mothers attending primary care units. Thus, this study aimed to characterize the profile of nursing mothers and infants seen in primary health care.

\section{METHODS}

This is a descriptive cross-sectional quantitative study. The population was composed of 135 nursing mothers registered in a primary health care unit of the IV Regional Health District of the municipality of Fortaleza, Ceará, Brazil.

Women who met the following inclusion criteria were interviewed: nursing mother of a child being consulted in the unit and being able to understand the interview questions. The exclusion criteria were nursing mothers who were unable to breastfeed because they had acquired immune deficiency syndrome (AIDS) and those who had psychiatric disorders.

The data were collected from May to October 2016 by trained collaborators who were participating in the Study and Research Group on Child and Adolescent Care at the State University of Ceará. A questionnaire designed by the researchers was used to collect data on sociodemographic and clinical information of the nursing mother and the infant.

The data obtained in this study were analyzed by descriptive statistics thereby transforming the information into quantifiable data. The data are presented in tables and discussed using relevant literature on the subject.

All the ethical care that governs research with human beings according to Resolution 466/2012, regulated by the National Health Council, were observed and respected. This study was approved by the Research Ethics Committee of the State University of Ceará (\#1.462.666).

\section{RESULTS AND DISCUSSION}

One hundred and thirty-five nursing mothers aged 15 to 42 years, with a mean age of 26.9 years, participated in the study. The majority of the mothers were aged between 20 and 35 years of age $(74.8 \%)$, followed by adolescent mothers with ages from 15 to 19 (14.1\%). The 20- to 35-year-old age group correlates to the childbearing age of the woman that is propitious for pregnancies.

It is well known that maternal age is a factor that influences breastfeeding, a fact corroborated by a study on the difficulties involved in breastfeeding, which shows that older women have more difficulties negatively affecting the continuation of breastfeeding. ${ }^{2}$ In addition, younger women have better access to information media with regard to the benefits and advantages of breastfeeding. ${ }^{7}$

Regarding the marital status, 56 participants (41.5\%) were in common law marriages, 54 women (40\%) were married in the registry office, and 25 (18.5\%) were single and so $81.5 \%$ lived with their spouses. This finding is in agreement with the literature, since the presence of a companion is important for support and encouragement, essential for the woman who breastfeeds. ${ }^{8}$ Hence, the involvement of the spouse by 
giving loving attention, affection and happiness to the woman are actions that strengthen her adherence to breastfeeding. ${ }^{9}$ The presence of the partner in the mother's social network is a positive influence for breastfeeding, especially in exclusive breastfeeding, and its absence may be a determining factor for early weaning. ${ }^{10}$

The schooling of the nursing mothers ranged from incomplete elementary school to completed college courses. The highest level of education was the most common degree of education (47.4\%), followed by incomplete secondary education (17.8\%). Nursing mothers with little schooling may not understand the real importance of breast milk to the lives of their newborns, its caloric and energetic contribution, and its influence on the child's growth and development, and thus some mothers fail to understand the need for exclusive breastfeeding the child. ${ }^{11}$

Regarding the mothers' employment, $64.5 \%$ of the nursing mothers performed only household activities, $32.6 \%$ had jobs and $2.9 \%$ had other sources of income. During this phase, formal work does not prevent a woman from breastfeeding if there are favorable conditions for her to continue, such as compliance with the time of maternity leave and spaces in the workplace specific for breastfeeding or hand expression. ${ }^{12}$

Regarding the obstetric profile, for the majority of participants this was their first child (48.9\%), for $36.3 \%$ of the women it was their second child and for $14.8 \%$ mothers it was at least their third. One of the factors that may justify the reduction of parity in today's society may be related to the increase in women's reproductive rights, in particular in respect to Law 9.263/1996, which regulates family planning in Brazil and offers assistance in conception and contraception, thereby providing possibilities for women to decide about their family size. ${ }^{13}$

The main place for prenatal follow-up was the primary care unit $(71.8 \%)$, followed by public hospitals $(31.1 \%)$ and private clinics $(17.1 \%)$; the mothers had between three and seven consultations in the prenatal period. Some nursing mothers reported having consulted both in primary care units and in private hospitals.

The primary care unit should be the preferred entry point for the pregnant woman into the health system, and the place that satisfies the mother-to-be needs the best with a longitudinal and continuous follow-up, especially during pregnancy. The consultations are interspersed between doctors and nurses, and it is recommended that the professionals who attend these women should stimulate and counsel on breastfeeding throughout the process. ${ }^{14}$ This may justify why some nursing mothers in this study were followed up in public hospitals.

Thus, the dissemination of information on breastfeeding is an important role for all health professionals, especially nurses, who should provide adequate and continuous support for the mother and her infant. ${ }^{15}$
Regarding the type of delivery, C-section (60\%) was the most commonly reported by the study participants. It is well known that cesarean delivery is a factor that hinders the start of breastfeeding, as women report pain and discomfort due to the surgery, making it difficult to position the child correctly. This may interfere with the woman's willingness to breastfeed and delay milk production. ${ }^{11}$ It is up to health professionals, particularly nurses, to assist these women in the unit, who often need support to start breastfeeding

The duration of gestation ranged from 38 to 42 weeks in the majority of mothers $(91.1 \%)$ with 12 women $(8.9 \%)$ having a gestation of 37 weeks or less. Despite the small number of women who had short gestations, it should be remembered that these women should be treated with special care because they require more encouragement and support for breastfeeding; these women are more vulnerable to early weaning. ${ }^{16}$

Furthermore, according to the guidelines proposed by the Ministry of Health, for full term pregnancies, the newborn should be placed promptly on the mother's breast, soon after clamping and cutting the umbilical cord. ${ }^{17} \mathrm{It}$ is worth mentioning that the mother and baby should be clinically well to perform the fourth step of breastfeeding. ${ }^{1}$

An important aspect in breastfeeding is the anatomy of the breasts, since many women consider it an adversity for the success of breastfeeding. Even though flat or inverted nipples may cause some difficulty in initiating breastfeeding, this does not prevent breastfeeding. It is at this moment that the support and knowledge of the health professional is essential so that the mother can successfully breastfeed.

The breast complications reported in this study, such as fissures, pain and mastitis, are similar to the results found by other authors, who correlated the complications, in general, to incorrect sucking on the nipple and the positioning of the baby. ${ }^{2,18}$ These results confirm the importance of the health professional regarding guidance and follow-up of nursing mothers for the breastfeeding process, intervening adequately to prevent possible complications and avoid early weaning. The presented data are described in Table 1.

Table 2 shows the profile of the infants; $51.1 \%$ were female and $48.9 \%$ male. The predominant birth weight range was between 2501 and 3500 grams (58.5\%). The age of the babies at data collection ranged from less than one month to six months, with the highest frequency being of newborns from one to four months $(57.0 \%)$. Most of the infants did not present any health problems at birth (68.3\%) with jaundice being the most common health problem (16.2\%).

One study reported that in newborns with postpartum complications, the prevalence of breastfeeding in the first hour after delivery is lower, which might be justified by the tests and interventions that are performed in these cases to the detriment of achieving of the fourth step of successful breastfeeding. ${ }^{19}$ 
Table 1. Sociodemographic and obstetric profile of nursing mothers. Fortaleza, Ceará, Brazil, 2016.

\begin{tabular}{|c|c|c|c|}
\hline Variable & $\mathbf{N}$ & $\%$ & Mean \pm SD \\
\hline Age & & & $26.89 \pm 6.45$ \\
\hline $15-19$ & 19 & 14.1 & \\
\hline $20-35$ & 101 & 74.8 & \\
\hline $36-42$ & 15 & 11.1 & \\
\hline \multicolumn{4}{|l|}{ Marital status } \\
\hline Common law marriage & 56 & 41.5 & \\
\hline Registry office marriage & 54 & 40.0 & \\
\hline Single & 25 & 18.5 & \\
\hline \multicolumn{4}{|l|}{ Schooling } \\
\hline Complete high school & 64 & 47.4 & \\
\hline Incomplete high school & 24 & 17.8 & \\
\hline Incomplete basic education & 19 & 14.1 & \\
\hline Complete further education & 11 & 8.1 & \\
\hline Incomplete further education & 10 & 7.4 & \\
\hline Complete basic education & 7 & 5.2 & \\
\hline \multicolumn{4}{|l|}{ Work activity } \\
\hline Home maker & 87 & 64.5 & \\
\hline Working & 44 & 32.6 & \\
\hline Others & 4 & 2.9 & \\
\hline \multicolumn{4}{|l|}{ Parity } \\
\hline One & 66 & 48.9 & \\
\hline Two & 49 & 36.3 & \\
\hline Three or more & 20 & 14.8 & \\
\hline \multicolumn{4}{|l|}{ Place of Prenatal $(n=162)^{*}$} \\
\hline Primary care & 97 & 71.8 & \\
\hline Specialized hospital & 42 & 31.1 & \\
\hline Private clinic & 23 & 17.1 & $7.89 \pm 2.21$ \\
\hline \multicolumn{4}{|l|}{ Number of consultations } \\
\hline $3-6$ & 31 & 22.9 & \\
\hline 7 or more & 104 & 77.1 & \\
\hline \multicolumn{4}{|l|}{ Delivery } \\
\hline C-section & 81 & 60.0 & \\
\hline Vaginal & 54 & 40.0 & $39.4 \pm 1.59$ \\
\hline \multicolumn{4}{|l|}{ Length of pregnancy } \\
\hline$\leq 37$ gestational weeks & 12 & 8.9 & \\
\hline 38-42 gestational weeks & 123 & 91.1 & \\
\hline \multicolumn{4}{|l|}{ Breast problems } \\
\hline None & 100 & 74.0 & \\
\hline Fissure & 17 & 12.5 & \\
\hline Pain & 10 & 7.4 & \\
\hline Injuries & 5 & 3.7 & \\
\hline Ingurgitation & 3 & 2.2 & \\
\hline \multicolumn{4}{|l|}{ Type of nipple } \\
\hline Adequate & 107 & 79.3 & \\
\hline Long & 12 & 8.9 & \\
\hline Flat & 6 & 4.4 & \\
\hline Inverted & 5 & 3.7 & \\
\hline Asymmetric & 5 & 3.7 & \\
\hline
\end{tabular}

SD: Standard deviation; * There were women who had prenatal care at two different places concomitantly.
Table 2. Profile of newborns and breastfeeding. Fortaleza, Ceará, Brazil, 2016.

\begin{tabular}{|c|c|c|c|}
\hline Variable & $\mathbf{N}$ & $\%$ & Mean \pm SD \\
\hline \multicolumn{4}{|l|}{ Gender } \\
\hline Female & 69 & 51.1 & \\
\hline Male & 66 & 48.9 & \\
\hline \multicolumn{4}{|l|}{ Birth weight } \\
\hline$\leq 2500$ & 4 & 2.9 & $3341.4 \pm 519.23$ \\
\hline $2501-3500$ & 79 & 58.5 & \\
\hline$\geq 3501$ & 52 & 38.6 & \\
\hline \multicolumn{4}{|l|}{ Age (months) } \\
\hline Less than 1 & 29 & 21.5 & \\
\hline $1-4$ & 77 & 57.0 & $2.6 \pm 1.99$ \\
\hline More than 5 & 29 & 21.5 & \\
\hline \multicolumn{4}{|c|}{$\begin{array}{l}\text { Health problems at birth } \\
(n=142)^{*}\end{array}$} \\
\hline None & 97 & 68.3 & \\
\hline Jaundice & 23 & 16.2 & \\
\hline Respiratory distress & 19 & 13.4 & \\
\hline Others & 3 & 2.1 & \\
\hline \multicolumn{4}{|l|}{$\begin{array}{l}\text { Time of exclusive } \\
\text { breastfeeding (months) }\end{array}$} \\
\hline Less than 1 & 25 & 18.5 & \\
\hline $1-4$ & 45 & 33.3 & \\
\hline $5-6$ & 9 & 6.6 & \\
\hline No breastfeeding & 56 & 41.4 & \\
\hline \multicolumn{4}{|l|}{ Difficulty to suck } \\
\hline Yes & 37 & 27.4 & \\
\hline No & 98 & 72.6 & \\
\hline
\end{tabular}

SD: Standard deviation; * Some newborns presented more than one problem at birth $(n=142)$.

Of those who were breastfed, the majority (33.3\%) were breastfed until the fourth month. Exclusive breastfeeding aims to ensure quality nurturing of the child; this practice promotes bonding between the mother and baby and is a cheap and safe way of feeding. However, several factors may interfere with this practice. $^{20}$

When the variable the first breastfeed was analyzed, $54.8 \%$ of the nursing mothers breastfed inside the delivery room. The empowerment of women in respect to their choices during childbirth should begin in prenatal care with discussions about the benefits of breastfeeding in the baby's first hour of life and the parturient's decision must be respected, making her an active participant in the achievement of the fourth step. ${ }^{19}$

The majority of the participating infants presented no difficulty in sucking the breast $(72.6 \%)$, which is a positive factor for the initiation of breastfeeding and contributes to 
the continuity of the process. An oral malformation might interfere with breastfeeding, making the process difficult and so evaluations of the child's mouth and its ability to breastfeed by the multiprofessional team are important in order to provide better assistance to the mother and baby. ${ }^{21}$

Breastfeeding is a complex process that includes cultural, social, biological and emotional factors. It is important to respect the desires of the nursing mother in this phase, as well as to offer counseling to promote breastfeeding. Counseling should be started during prenatal care so that the pregnant woman understands the correct manner of breastfeeding and its benefits for the mother and her baby. ${ }^{22}$

Due to difficulties, many mothers find a solution of keeping their babies healthy and nourished using infant formulas, as it is a food that will always be available. In addition, the manufacturers, by the use of advertising, have convinced many women that powdered milk is an excellent substitute, reporting that it is practical, prepared in optimal hygienic conditions and has a varied amount of vitamins, thus meeting the nutritional needs of the infant. ${ }^{23}$

Although mothers sometimes do not understand the context of breastfeeding or are not yet familiar with their maternal role, most recognize the importance of breastfeeding for their children. ${ }^{5}$ Therefore, failure to breastfeed causes negative feelings for nursing mothers, that demands a multidisciplinary humanized care approach that welcomes and supports the nursing mother to cope with difficulties. ${ }^{24}$

In this context, counseling that promotes breastfeeding favors the continuity of this process; the nurse, who has scientific and technical knowledge about the practice of breastfeeding, is an important agent in accomplishing this strategy. Thus, the nurse is one of several professionals responsible for the success or failure of the breastfeeding process..$^{22}$ It is possible to observe a degree of empathy and complicity in relationships between nursing mothers and health professionals which helps to create a bond of security and support. ${ }^{9}$

In addition, the continued support of health professionals with their welcoming at health facilities, participation in support groups, home visits and during breastfeeding is of paramount importance as these are determining factors for better adherence of mothers to breastfeeding. With this in mind, it is understood that health professionals are the main actors responsible for the promotion and maintenance of breastfeeding because they are the ones who, with their skills and technical training, can provide the most support and information during breastfeeding, pregnancy and in the postpartum period. ${ }^{2}$

The relevance of breastfeeding to the health of women and children is well known by health professionals and, therefore, we should not fail to offer the necessary information to nursing mothers in order to achieve compliance to breastfeeding.

\section{CONCLUSIONS}

Breastfeeding is an act of great relevance to the infant, however it is noticed that, often, nursing mothers consulted in health services are not complying with the recommendations of the Ministry of Health. Exclusive breastfeeding rates are below recommended.

The participants of this study were young women of childbearing age with good schooling, however, breastfeeding rates were low. Although it is a widely discussed topic, it is still necessary to improve counseling through health education in primary health care units, since the act of breastfeeding is important to the health of the woman and her child. It should be taken into account that breast milk is the ideal food to satisfy the needs of the infant. Thus, the responsibility of the health team, in particular the nurse, is to develop educational activities that sensitize the nursing mothers who are consulted in health services.

The limitation of this study was the demographic coverage, since it was performed in only one primary care unit. However, it identified the behavior of these women related to breastfeeding, which was in agreement with what is published in the literature. It is suggested that a posteriori, the study can be applied in other regions to compare the profile of breastfeeding mothers in different regions.

\section{REFERENCES}

1. Ministério da Saúde (BR). Secretaria de Atenção à Saúde. Departamento de Atenção Básica. Saúde da criança: aleitamento materno e alimentação complementar. $2^{\underline{a}}$ ed. Brasília (DF): Ministério da Saúde; 2015 [cited 2016 Dec 17]. 184 p. Available from: http://bvsms.saude. gov.br/bvs/publicacoes/saude_crianca aleitamento materno_cab23. pdf

2. Sousa ASB. Dificuldades do aleitamento materno [Dissertação]. Viseu: Instituto Superior Politécnico de Viseu; 2016

3. Giugliani ERJ, Lamounier JA. Aleitamento materno: uma contribuição científica para a prática do profissional de saúde. J Pediatr (Rio J.) [Internet]. 2004; [cited 2017 Nov 01]; 80(5 Suppl):s117-s118. Available from: http://www.scielo.br/scielo.php?script=sci arttext\&pid=S0021-75572004000700001\&Ing=en. DOI: $10.1590 /$ S0021-75572004000700001

4. Batista KRA, Farias MCAD, Melo WSN. Influência da assistência de enfermagem na prática da amamentação no puerpério imediato. Saúde Debate [Internet]. 2013 Jan/Mar; [cited 2017 Jul 24]; 37(96):130-8. Available from: http://www.scielo.br/pdf/sdeb/v37n96/15.pdf. DOI: 10.1590/S0103-11042013000100015

5. Castelli CTR, Maahs MAP, Almeida ST. Identification of the doubts and difficulties of pregnant and postpartum women related to breastfeeding Rev CEFAC [Internet]. 2014; [cited 2017 Nov 1]; 16(4):1178-86. Available from: http://www.scielo.br/scielo.php?script=sci arttext\&pid=S151618462014000401178\&Ing=en. DOI: 10.1590/1982-0216201411713

6. Almeida IS, Ribeiro IB, Rodrigues BMD, Costa CCP, Freitas NS Vargas EB. Amamentação para mães primíparas: perspectivas e intencionalidades do enfermeiro ao orientar. Cogitare Enferm [Internet]. 2010; [cited 2017 Oct 31]; 15(1):19-25. Available from http://www.revenf.bvs.br/scielo.php?script=sci_arttext\&pid=S1414$85362010000100003 \&$ Ing $=$ es 
7. Simões IAR, Rennó G, Salomon ASC, Martins MCM, Sá RAD. Influência dos Mitos e das Crenças nas Nutrizes Quanto Amamentação em uma Cidade do Vale do Paraíba. Rev Ciênc Saúde [Internet]. 2015 [cited 2017 Nov 1]; 5(3):[about 9p.]. Available from: http://200.216.240.50:8484/ rcsfmit/ojs-2.3.3-3/index.php/rcsfmit_zero/article/view/385. DOI: 10.21876/rcsfmit.v5i3.385

8. Marques ES, Cotta RMM, Priore SE. Mitos e crenças sobre o aleitamento materno. Ciênc Saúde Coletiva. [Internet]. 2011; [cited 2017 Nov 2]; 16(5):2461-8. Available from: http://www.scielo.br/scielo. php?script=sci_arttext\&pid=S1413-81232011000500015\&Ing=en. DOI: $10.1590 / \mathrm{S} 1413-81232011000500015$

9. Primo CC, Dutra PR, Lima EFA, Alvarenga SC, Leite FMC. Redes sociais que apoiam a mulher durante a amamentação. Cogitare Enferm [Internet]. 2015; [cited 2017 Nov 3]; 20(2):426-33. Available from: http://revistas. ufpr.br/cogitare/article/view/37453. DOI: 10.5380/ce.v20i2.37453

10. Nardi AL, Gusmão RC, Carvalho NM. Estudos de caso sobre amamentação: da gestação aos seis meses de vida. Rev APS [Internet]. 2014 Oct/Dec; [cited 2016 Nov 6]; 17(4):507-15. Available from: https:// aps.uff.emnuvens.com.br/aps/article/view/2091/845

11. Margotti E, Epifanio M. Exclusive maternal breastfeeding and the Breastfeeding Self-efficacy Scale. Rev Rene [Internet]. 2014 Sep/ Oct; [cited 2016 Sep 20]; 15(5):771-9. Available from: http://www. periodicos.ufc.br/rene/article/view/3240/2495. DOI: 10.15253/21756783.2014000500006

12. Souza NKT, Medeiros MP, Silva MA, Cavalcanti SB, Dias RS, Valente FA. Aspectos envolvidos na interrupção do aleitamento materno exclusivo. Com Ciênc Saúde [Internet]. 2011; [cited 2016 Oct 29]; 22(4):231-8. Available from: http://bvsms.saude.gov.br/bvs/periodicos/ revista_ESCS_V22_n3_a05_aspectos_envolvidos_interrupcao.pdf

13. Lei $n-9.263$ de 12 de janeiro de 1996 (BR). Regula Planejamento Familiar. Brasília (DF): Diário Oficial da União; 12 Jan 1996 [cited 2016 Oct 24]. Available from: http://www.planalto.gov.br/ccivil_03/leis/L9263.htm

14. Ministério da Saúde (BR). Secretaria de Atenção à Saúde. Cadernos de Atenção Básica. Atenção ao pré-natal de baixo risco. Brasília (DF): Ministério da Saúde; 2012 [cited 2016 Nov 2] 318 p. Available from: http://189.28.128.100/dab/docs/publicacoes/geral/caderno_atencao_ pre_natal_baixo_risco.pdf

15. Santos LCE. Políticas públicas em aleitamento materno. In: Carvalho RM, Tavares LAM. Amamentação: bases científicas. $3^{\mathrm{a}}$ ed. Rio de Janeiro: Guanabara Koogan; 2014. p. 277-85.

16. Sassá $H$, Schmidt KT, Rodrigues BC, Ichisato SMT, Higarashi IH, Marcon SS. Bebês pré-termo: aleitamento materno e evolução ponderal. Rev Bras Enferm. [Internet]. 2014; [cited 2017 Nov 1]; 67(4):594-600. Available from: http://www.redalyc.org/html/2670/267032000015/.DOI: 10.1590/0034-7167.2014670415
17. Ministério da Saúde (BR). Secretaria de Atenção à Saúde. Departamento de Ações Programáticas Estratégicas. Atenção à saúde do recém-nascido: guia para os profissionais de saúde. Brasília (DF) Ministério da Saúde; 2011 [cited 2017 Nov 2]. 1v. Available from: http:// bvsms.saude.gov.br/bvs/publicacoes/atencao_saude_recem_nascido_profissionais_v1.pdf

18. Fernández Medina IM, González Fernández CT. Lactancia materna: prevención de problemas tempranos en las mamas mediante una técnica de amamantamiento eficaz. Enferm Glob [Internet]. $2013 \mathrm{Jul}$; [cited 2016 Sep 17]; 12(3):443-51. Available from: http:// revistas.um.es/eglobal/article/view/157781/150151. DOI: 10.6018/ eglobal.12.3.157781

19. Bocolini CS, Carvalho ML, Oliveira MIC, Vasconcellos AGG. Factors associated with breastfeeding in the first hour of life. Rev Saude Publica [Internet]. 2011; [cited 2016 Oct 5]; 45(1):69-78. Available from: http:// www.scielo.br/pdf/rsp/v45n1/en_1717.pdf. DOI: 10.1590/S003489102010005000051

20. Pellegrinelli ALR, Pereira SCL, Ribeiro IP, Santos LC. Influência do uso de chupeta e mamadeira no aleitamento materno exclusivo entre mães atendidas em um Banco de Leite Humano. Rev Nutr [Internet].2015; [cited 2017 Nov 6]; 28(6):631-9. Available from: http://www.scielo.br/scielo. php?script=sci_arttext\&pid=S1415-52732015000600631\&lng=en . DOI: $10.1590 / 1415-52732015000600006$

21. Sanches MTC. Clinical management of oral disorders in breastfeeding J Pediatr (Rio J) [Internet]. 2004; [cited 2016 Sep 28]; 80(5):S155-S162. Available from: $\mathrm{http}: / / \mathrm{www}$. scielo.br/pdf/jped/v80n5s0/en_v80n5s0a07. pdf. DOI: 10.1590/S0021-75572004000700007

22. Azevedo ARR, Alves VH, Souza RMP, Rodrigues DP, Branco MBLR, Cruz AFN. Clinical management of breastfeeding: knowledge of nurses. Esc Anna Nery [Internet]. 2015; [cited 2016 Dec 8]; 19(3):43945. Available from: http://www.scielo.br/scielo.php?pid=S1414 $81452015000300439 \&$ script=sci_arttext\&tlng=en. DOI: $10.5935 / 1414$ 8145.20150058

23. Campos FKL, Rodrigues JC, Lima ACS, Caldas DRC, Simplicio APM, Landim LASR. Determining Factors Related to Breastfeeding. ReonFacema [Internet]. 2016 Oct/Dec; [cited 2017 Nov 2]; 2(4):297303. Available from: www.facema.edu.br/ojs/index.php/ReOnFacema/ article/download/98/68

24. Silveira JGC, Weise CM. Representações Sociais das Mães de Crianças Portadoras de Fissuras Labiopalatinas sobre Aleitamento. Pesq Bras Odontoped Clin Integr [Internet]. 2008 May/Aug; [cited 2016 Aug 27]; 8(2):215-21. Available from: http://revista.uepb.edu.br/index. php/pboci/article/view/297/215. DOI: 10.4034/1519.0501.2008.0082. 0015 